American Journal of Environmental Sciences 2 (3): 95-103, 2006

ISSN 1553-345X

(c) 2006 Science Publications

\title{
An Assessment of Mirex Concentrations along the Southern Shorelines of the Great Lakes, USA
}

\author{
Dennis A. Apeti and Gunnar G. Lauenstein \\ Center for Coastal Monitoring and Assessment, NOAA 1305 East West Highway \\ Silver Spring, MD 20910, USA
}

\begin{abstract}
Mirex is a persistent and toxic polychlorinated pesticide that has compromised environmental quality in the Great Lakes region since the 1960s. As a bioaccumulative and carcinogenic compound, mirex at its current levels in Lake Ontario is a concern because of the potential for trophic level transfer and biomagnification in top predators. As a part of the NOAA's National Status and Trends Program (NS\&T), zebra mussels and surficial sediments were surveyed throughout the Great Lakes since 1992 to monitor a broad suite of contaminants, including mirex. The non-parametric Wilcoxon test revealed that Lake Ontario consistently had the highest mirex concentrations $(\mathrm{p}<0.0054)$ followed by Lake Erie while Lakes Huron and Michigan had the lowest concentrations. Current concentrations of mirex at Lake Ontario sites are at or above the NS\&T benchmark of $85^{\text {th }}$ percentile ( $2.33 \mathrm{ng} \mathrm{g}^{-1}$ dry weights) determined among all sites in the Great Lakes. The Spearman correlation statistic revealed an overall decreasing trend in tissue concentration, but this decline is only significant in Lake Ontario $(\mathrm{p}<0.02)$ over the monitoring period 1992-2004. Photodegradation, volatilization, fishing and loss via the St Lawrence River are discussed as mechanisms resulting in the mirex decline.
\end{abstract}

Key words: Mirex, mussel watch, contamination, persistent chemicals, zebra mussels, bioaccumulation, biomagnification, ecotoxicity

\section{INTRODUCTION}

In 1986, the National Oceanic and Atmospheric Administration (NOAA) initiated nationwide coastal monitoring for a suite of organic and inorganic contaminants under the National Status and Trends (NS\&T) Mussel Watch Project (MWP) using bivalve mollusks as sentinel organisms. In 1992, the MWP expanded into the Great Lakes (Fig. 1) and included measurements of contaminants in zebra and quagga mussels (Dreissena polymorpha and D. bugensis). Although non-native to the Great Lakes, Dreissena spp. were selected as sentinels because they have become dominant, displacing the native unionid clams $^{[1]}$. A suite of more than 120 contaminants measured by the $\mathrm{MWP}^{[2]}$ is quantified in the Great Lakes, including mirex.

Mirex, $\mathrm{C}_{10} \mathrm{Cl}_{12}$ (Fig. 2), is a synthetic multifunctional organochlorine compound, initially used as a pesticide and later as a flame-retardant ${ }^{[3]}$. The US Environmental Protection Agency (US EPA) has classified mirex as a level-1 contaminant (Persistent Bioaccumulative and Toxic) and its production and use in the US were banned in $1977^{[4]}$. As a fully saturated organochlorine, mirex is strongly resistant to biodegradation and its lipophilic property ( $\log \mathrm{k}_{\mathrm{ow}}$ of 7.13) indicates a strong bioaccumulative capacity ${ }^{[4-6]}$. Consequently, top predators such as lake trout and piscivorous birds (ospreys and herring gulls) have been reported to contain high concentrations because mirex is biomagnified along the food chain ${ }^{[7]}$. Ecotoxicity of mirex has been associated with tumors in fish and egg shell thinning in piscivorous birds ${ }^{[3]}$. Based on evidence in experimental animals, the Agency for Toxic Substances and Disease Registry ${ }^{[8]}$ has anticipated mirex to be a potential human carcinogen. Recent studies indicate that human inhabitants of the Great Lakes region consume significant amounts of sportfish such as lake trout ${ }^{[9,10]}$ thus, there is a concern that human populations are being chronically exposed to mirex in the Great Lakes region ${ }^{[9]}$.

Sources of mirex contamination have been linked to two chemical plants in the Great Lakes. These include Hooker Chemical and Armstrong Cork Company, both of which released mirex into the Niagara and Oswego Rivers in the 1960s respectively ${ }^{[11,12]}$. As the primary receiving basin of these rivers, Lake Ontario became the most polluted with mirex ${ }^{[11,13]}$. Mirex is now ubiquitous in the Great Lakes system due to hydrological transport, migration of contaminated fish, and non-point sources associated with land application of the pesticide ${ }^{[3]}$. First reported in $1978^{[14]}$, mirex pollution in the Great Lakes has become the subject of major monitoring and assessment activities because of its ecotoxicity and potential human health hazards ${ }^{[13,15]}$. 
Before the MWP, long-term biomonitoring in the Great Lakes was centered on the use of herring gull eggs (Larus argentatus) as an indicator of persistent environmental contaminants ${ }^{[16]}$. Although the Great Lakes Herring Gull Monitoring Program has an extensive dataset that provides useful temporal trends, it does not include contaminant loading in sediments, nor is it exclusively based on aquatic organisms. The MWP complements the Herring Gull Monitoring Program by providing contaminant data for bottom sediments and soft bivalve tissues. As sessile filter-feeders, bivalves are generally considered better indicators because exogenous chemical contents in their tissue reflect contaminant loadings of their immediate surroundings ${ }^{[17]}$.

It is well documented that bivalves such as mussels can bioconcentrate organic contaminants to levels that are many orders of magnitude greater than those in their immediate surroundings ${ }^{[18,19]}$. The ability of bivalves to remove contaminants is detrimental to the ecosystem because of the potential trophic level transfer of contaminants through the food chain. In the Great Lakes, zebra mussels are being foraged upon by several fish species ${ }^{[20-22]}$, which promotes the trophic transfer of mirex as well as other contaminants to higher order predators. This is an emerging concern in the Great Lakes region particularly in the western counties of the State of New York where sportfish from Lake Ontario are often consumed ${ }^{[10]}$. The purpose of this paper is to examine the recent spatial distribution and temporal trends of mirex in the Great Lakes southern shoreline.

\section{MATERIALS AND METHODS}

The MWP monitors contaminants in both sediments and bivalve tissues at 280 sites around the nation, including the 24 sites of the Great Lakes (Fig. 1 and Table 1). While the MWP initially established seven monitoring sites in Lakes St. Clair, Erie and Huron, monitoring sites now exist in all of the Great Lakes with the exception of Lake Superior (Fig. 1). Field sampling and laboratory analysis follow protocols documented by the MWP ${ }^{[2,23]}$. Bivalves were collected on a biennial basis with Lakes Michigan and Huron sites sampled during one year and the remaining sites collected in the alternate year. Zebra mussels were hand collected by snorkeling or with the use of an epibenthic dredge. From 1992 through 1994 triplicates of 30 mussel composites were collected at each site and after 1994 only one composite is collected for mirex analysis. The MWP collects sediments every ten years; however, in the Great Lakes, sites were only collected once since 1992. Sediments were collected using a Ponar-grab and sub-sampled with a Kynar coated scoop. Collected in triplicate, sediment samplings were limited to sites with fine grain substrates. With that criterion, some sites in Lakes Michigan (LMCB and LMNC) and Huron (TBLL, LHTB and SBSP) were not collected due to the sandy nature of the bottom sediment. Refer to Table 1 for the definition of sites acronyms used in this report. In the laboratory, individual mussels were cleaned, sized (length and weight), shucked and composites of whole soft tissue homogenized.

Table 1: Mussel Watch sites in the Great Lakes

\begin{tabular}{|c|c|c|c|c|c|}
\hline \multirow[t]{2}{*}{ Site Acronym } & \multirow[t]{2}{*}{ General location } & \multirow[t]{2}{*}{ Specific location } & \multirow[t]{2}{*}{ State } & \multicolumn{2}{|l|}{ Location } \\
\hline & & & & Latitude $(\mathrm{N})$ & Longitude (W) \\
\hline GBBS & Green Bay & Bayshore Park & WI & $44^{\circ} 38.22^{\prime}$ & $87^{\circ} 48.49^{\prime}$ \\
\hline LMMB & Lake Michigan & Milwaukee Bay & WI & $43^{\circ} 01.93^{\prime}$ & $87^{\circ} 53.71^{\prime}$ \\
\hline LMNC & Lake Michigan & North Chicago NTC & IL & $42^{\circ} 18.28^{\prime}$ & $87^{\circ} 49.64^{\prime}$ \\
\hline LMCB & Lake Michigan & Calumet Breakwater & IN & $41^{\circ} 43.63^{\prime}$ & $87^{\circ} 29.70^{\prime}$ \\
\hline LMHB & Lake Michigan & Holland Breakwater & MI & $42^{\circ} 46.39^{\prime}$ & $86^{\circ} 12.90^{\prime}$ \\
\hline LMMU & Lake Michigan & Muskegon Breakwater & MI & $43^{\circ} 13.55^{\prime}$ & $86^{\circ} 20.82^{\prime}$ \\
\hline TBLL & Traverse Bay & Leelanau State Park & MI & $45^{\circ} 12.34^{\prime}$ & $85^{\circ} 32.21^{\prime}$ \\
\hline LHTB & Lake Huron & Thunder Bay & MI & $44^{\circ} 55.33^{\prime}$ & $83^{\circ} 24.81^{\prime}$ \\
\hline SBSP & Saginaw Bay & Sandy Point & MI & $43^{\circ} 54.59^{\prime}$ & $83^{\circ} 24.01^{\prime}$ \\
\hline SBSR & Saginaw Bay & Saginaw River & MI & $43^{\circ} 40.41^{\prime}$ & $83^{\circ} 50.20^{\prime}$ \\
\hline LHBR & Lake Huron & Black River Canal & MI & $43^{\circ} 02.66^{\prime}$ & $82^{\circ} 26.32^{\prime}$ \\
\hline LSAB & Lake St. Clair & Anchor Bay & MI & $42^{\circ} 38.95^{\prime}$ & $82^{\circ} 42.66^{\prime}$ \\
\hline LESP & Lake Erie & Stony Point & MI & $41^{\circ} 57.52^{\prime}$ & $83^{\circ} 13.98^{\prime}$ \\
\hline LERB & Lake Erie & Reno Beach & $\mathrm{OH}$ & $41^{\circ} 40.47^{\prime}$ & $83^{\circ} 13.57^{\prime}$ \\
\hline SBPP & South Bass Island & Peach Orchard Pt. & $\mathrm{OH}$ & $41^{\circ} 39.58^{\prime}$ & $82^{\circ} 49.50^{\prime}$ \\
\hline LEOW & Lake Erie & Old Woman Creek & $\mathrm{OH}$ & $41^{\circ} 23.10^{\prime}$ & $82^{\circ} 31.12^{\prime}$ \\
\hline LELR & Lake Erie & Lorain & $\mathrm{OH}$ & $41^{\circ} 27.67^{\prime}$ & $82^{\circ} 12.42^{\prime}$ \\
\hline LEAB & Lake Erie & Ashtabula & $\mathrm{OH}$ & $41^{\circ} 55.48^{\prime}$ & $80^{\circ} 43.10^{\prime}$ \\
\hline LEDK & Lake Erie & Dunkirk & NY & $42^{\circ} 31.75^{\prime}$ & $79^{\circ} 16.66^{\prime}$ \\
\hline NRNF & Niagara River & Niagara Falls & NY & $43^{\circ} 02.81^{\prime}$ & $78^{\circ} 53.52^{\prime}$ \\
\hline LOOC & Lake Ontario & Olcott & NY & $43^{\circ} 21.32^{\prime}$ & $78^{\circ} 41.20^{\prime}$ \\
\hline LORC & Lake Ontario & Rochester & NY & $43^{\circ} 15.47^{\prime}$ & $77^{\circ} 29.72^{\prime}$ \\
\hline LOOS & Lake Ontario & Oswego & NY & $43^{\circ} 27.17^{\prime}$ & $76^{\circ} 33.05^{\prime}$ \\
\hline LOCV & Lake Ontario & Cape Vincent & NY & $44^{\circ} 08.65^{\prime}$ & $76^{\circ} 19.48^{\prime}$ \\
\hline
\end{tabular}


Table 2: Mirex concentration (ng/g dry weight) in zebra mussels (2002-2003) and sediments in the Great Lakes. $85^{\text {th }}$ and $50^{\text {th }}$ percentiles concentrations among all collected sites in the Great Lakes

\begin{tabular}{|c|c|c|c|c|c|c|c|c|c|c|}
\hline \multirow[t]{2}{*}{ Site } & \multirow[t]{2}{*}{ Lakes } & \multirow[t]{2}{*}{ States } & \multicolumn{4}{|l|}{ Mussels } & \multicolumn{4}{|l|}{ Sediment } \\
\hline & & & Mirex & $\mathrm{n}$ & $85^{\text {th }}$ & $50^{\text {th }}$ & Mirex & $\mathrm{n}$ & $85^{\text {th }}$ & $50^{\text {th }}$ \\
\hline & & & (ng/g dw) & & & & (ng/g dw) & & & \\
\hline GBBS & Michigan & WI & 0 & 1 & 2.33 & 0.14 & 0 & 1 & 0.61 & 0.07 \\
\hline LMMB & Michigan & WI & 0.091 & 1 & 2.33 & 0.14 & $0.55 \pm 0.19$ & 3 & 0.61 & 0.07 \\
\hline LMNC & Michigan & IL & 0.16 & 1 & 2.33 & 0.14 & ND & & & \\
\hline LMHB & Michigan & MI & 0.12 & 1 & 2.33 & 0.14 & $0.08 \pm 0.01$ & 3 & 0.61 & 0.07 \\
\hline LMHM & Michigan & IN & 0.17 & 1 & 2.33 & 0.14 & ND & & & \\
\hline LMMU & Michigan & MI & 0.16 & 1 & 2.33 & 0.14 & $0.13 \pm 0.01$ & 3 & 0.61 & 0.07 \\
\hline TBLL & Michigan & MI & 0 & 1 & 2.33 & 0.14 & ND & & & \\
\hline LHTB & Huron & MI & 0 & 1 & 2.33 & 0.14 & ND & & & \\
\hline SBSR & Huron & MI & 0 & 1 & 2.33 & 0.14 & 0 & 1 & 0.61 & 0.07 \\
\hline SBSP & Huron & MI & 0 & 1 & 2.33 & 0.14 & ND & & & \\
\hline LHBR & Huron & MI & 0 & 1 & 2.33 & 0.14 & 0 & 1 & 0.61 & 0.07 \\
\hline LSAB & St.Clair & MI & 0 & 1 & 2.33 & 0.14 & 0 & 1 & 0.61 & 0.07 \\
\hline LELR & Erie & $\mathrm{OH}$ & 0.14 & 1 & 2.33 & 0.14 & 0 & 1 & 0.61 & 0.07 \\
\hline LEAB & Erie & $\mathrm{OH}$ & 0.19 & 1 & 2.33 & 0.14 & 0 & 3 & 0.61 & 0.07 \\
\hline LEDK & Erie & NY & 0.22 & 1 & 2.33 & 0.14 & 0 & 3 & 0.61 & 0.07 \\
\hline LEOW & Erie & $\mathrm{OH}$ & 0 & 1 & 2.33 & 0.14 & 0.73 & 1 & 0.61 & 0.07 \\
\hline LERB & Erie & $\mathrm{OH}$ & 0.069 & 1 & 2.33 & 0.14 & ND & & & \\
\hline LESP & Erie & MI & 0.14 & 1 & 2.33 & 0.14 & 0 & 1 & 0.61 & 0.07 \\
\hline SBPP & Erie & NY & 0.16 & 1 & 2.33 & 0.14 & 0 & 1 & 0.61 & 0.07 \\
\hline NRNF & Niagara River & NY & 1.1 & 1 & 2.33 & 0.14 & ND & & & \\
\hline LOOC & Ontario & NY & 3.6 & 1 & 2.33 & 0.14 & $0.93 \pm 0.17$ & 3 & 0.61 & 0.07 \\
\hline LORC & Ontario & NY & 3.6 & 1 & 2.33 & 0.14 & $0.29 \pm 0.01$ & 3 & 0.61 & 0.07 \\
\hline LOOS & Ontario & NY & 2.5 & 1 & 2.33 & 0.14 & 0 & 1 & 0.61 & 0.07 \\
\hline LOCV & Ontario & NY & 2.3 & 1 & 2.33 & 0.14 & $0.25 \pm 0.02$ & 3 & 0.61 & 0.07 \\
\hline
\end{tabular}

Concentrations in sediments are average \pm standard error. ND denotes not determined.

Table 3: Temporal trends analyses of mirex concentrations using the nonparametric Spearman rank correlation. (a) Assessment of trends in the major Great Lakes monitored by the MWP. (b) Assessment of trends at the four sites in Lake Ontario

\begin{tabular}{lllllll}
\hline (a) & & & & & & \\
(b) & & & \\
Major lakes & $\mathrm{r}$ & $\mathrm{p}$ & $\mathrm{n}$ & Site in Lake Ontario & $\mathrm{r}$ & $\mathrm{p}$ \\
\hline Michigan & 0.42 & 0.30 & 8 & Olcott (LOOC) & -0.77 & 0.07 \\
Huron & -0.38 & 0.22 & 12 & Rochester (LORC) & -0.94 & 0.005 \\
Erie & -0.10 & 0.86 & 9 & Oswego (LOOS) & -0.83 & 0.04 \\
Ontario & -0.89 & 0.02 & 6 & Cape Vincent (LOCV) & -0.83 & 0.04 \\
\hline
\end{tabular}

$(\mathrm{r})$ is the spearman correlation coefficient between mirex concentration and year, (p) is the probability associated with the significance of the correlation at $95 \%$ confidence level, and (n) is the number of years specific sites were collected since 1992.

Sediment samples were prepared by removing all pebbles, shells, biota and other detritus before being homogenized using a spatula. After being fractionated by size-exclusion by High Performance Liquid Chromatography (HPLC), homogenates of both sediment and tissue were quantified for mirex content using gas chromatography coupled with electron capture detector $^{[2]}$. Results were reported on a dry weight basis and the MWP data is available on the web at http://ccma.nos.noaa.gov/cit/data. Mirex concentrations (tissues and sediments) at the 24 sites of the Great Lakes were averaged by site and year where multiple stations were collected to conduct spatial and temporal trends assessment respectively. Concentrations at each site are presented as arithmetic mean of triplicate samples (1992-1994) and a single homogenate thereafter. The annual concentrations for each lake are arithmetic means of all sites collected each year.

Statistical analyses were conducted using JMP$5.1^{\mathrm{TM}}$ and $\mathrm{SAS}^{\mathrm{TM}}$. Because the survey data were not normally distributed (Kolmogorov-Smirnov test), differences among sites and trends of mirex concentrations, were examined using the nonparametric Wilcoxon-Signed-Rank Test and Spearman correlation. Rather than comparing site concentrations to lake-wide means, mirex concentrations at each site were ranked into percentiles $\left(15^{\text {th }}, 50^{\text {th }}\right.$ and $\left.85^{\text {th }}\right)$ using the sediment data and the more recent 2002-2003 tissue data (Table 2). Percentiles ranking categorizes site concentrations into low $\left(<15^{\text {th }}\right)$, medium-low $\left(15^{\text {th }}\right.$ to $\left.50^{\text {th }}\right)$, mediumhigh $\left(50^{\text {th }}\right.$ to $\left.85^{\text {th }}\right)$ and high ( $>85^{\text {th }}$ percentiles) concentrations. Thus, the $85^{\text {th }}$ percentile identifies the top $15 \%$ of the sites that have the highest mirex concentrations $^{[24]}$.

\section{RESULTS AND DISCUSSION}

Spatial distribution: The sediment and tissue data indicate that with the exception of Lake Huron, residues of mirex occur in Great Lakes' water bodies monitored by the MWP (Fig. 3 and 4). Lake Ontario exhibits the highest levels $(p<0.0054)$ of mirex in both sediment 


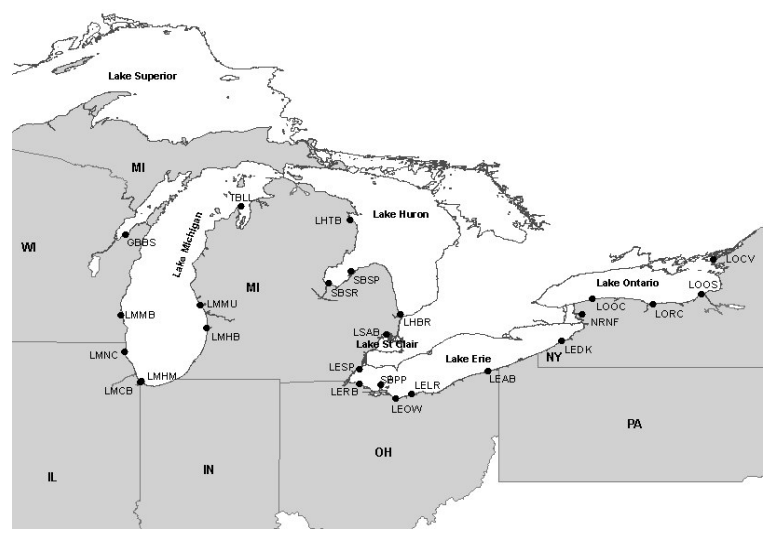

Fig. 1: Map of the Great Lakes region showing the 24 Mussel Watch project sites

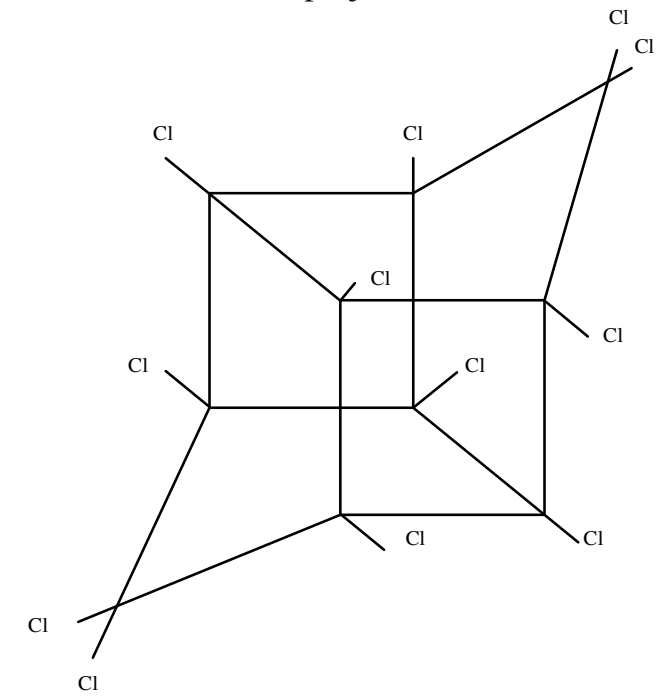

Fig. 2: Molecular structure of mirex $\left(\mathrm{C}_{10} \mathrm{Cl}_{12}\right)$ a fully saturated organochlorine pesticide

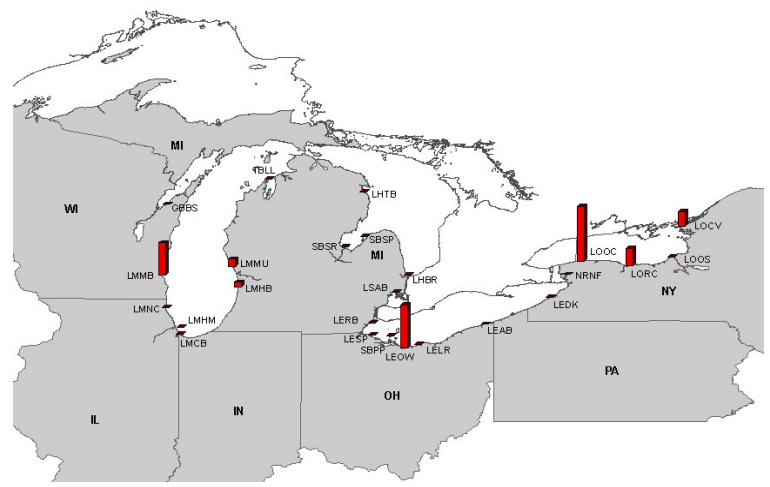

Fig. 3: Map of the Great Lakes region showing the spatial distribution of mirex (ng/dry g) in surficial sediments

and tissue matrices with the most recent concentrations ranging from undetected to $0.93 \mathrm{ng} \mathrm{g}^{-1}$ in sediments and 2.28 to $3.58 \mathrm{ng} \mathrm{g}^{-1}$ in tissues (Table 2). In Lake Ontario, mirex concentrations in tissue were above the $85^{\text {th }}$ percentile concentration of $2.33 \mathrm{ng} \mathrm{g}^{-1}$. Mirex concentrations in sediment however, were more

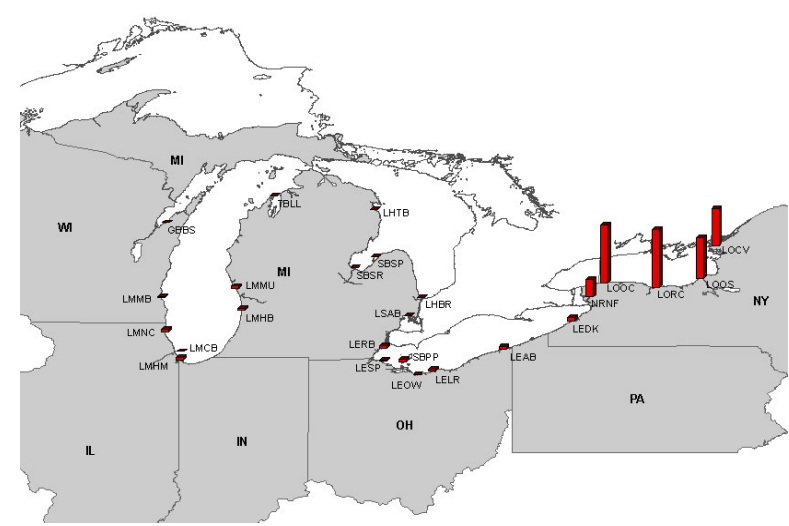

Fig. 4: Map of the Great Lakes region showing the spatial distribution of mirex (ng/ dry g) in Derissena sp. collected in 2002-2003

disperse with the Milwaukee Bay (LMMB), Old Woman (LEOW) and Olcott (LOOC) sites having sediment mirex concentrations at or above the corresponding $85^{\text {th }}$ percentile $\left(0.61 \mathrm{ng} \mathrm{g}^{-1}\right)$. Moreover, the spatial distribution shows that mirex concentrations (Fig. 3 and 4) at Niagara Falls, Lakes Erie, Huron, Michigan and St. Clair ranged in general from nondetected to medium based on the percentile criteria.

Temporal trends: Temporal trends of mirex concentrations in the Great Lakes were assessed using the tissue concentrations only. Sediment concentrations were not adequate for trends assessment because each site was collected only once since the MWP started monitoring the coastal waters of the Great Lakes. Analyses of temporal trends of mirex concentrations in the Great Lakes were performed using the nonparametric Spearman correlation. With the exception of Lake Michigan, the Spearman correlation coefficients are negative indicating net decreasing trends over time (Table 3a). Additionally, the nonparametric Wilcoxon Signed-Ranks test shows an overall decrease of mirex concentration in mussel tissue in the Great Lakes since 1992 (Fig. 5 and 6). On average, mirex concentration in the Great Lakes has declined by $83 \%$ over the monitoring period 19922004. Although a decreasing trend was observed in the Great Lakes overall, the patterns was driven by Lake Ontario where mirex concentrations have dramatically declined $(\mathrm{p}<0.02)$. Trends for the other lakes were not significant. Further assessment of the temporal trends at the four specific sites in Lake Ontario revealed that with the exception of the Lake Ontario-Olcott (LOOC) site, decreasing mirex concentrations are significantly correlated with time (Table 3b). In Lake Ontario, concentrations as high as $23 \mathrm{ng} \mathrm{g}^{-1}$ were recorded in 1995, but a decade later the highest concentration was only $3.58 \mathrm{ng} \mathrm{g}^{-1}$ corresponding to a decrease of $85 \%$ (Fig. 6). The rapid decline in mirex concentration reported here is in agreement with published results by Makarewicz et al. ${ }^{[25]}$ who has reported decrease of more 

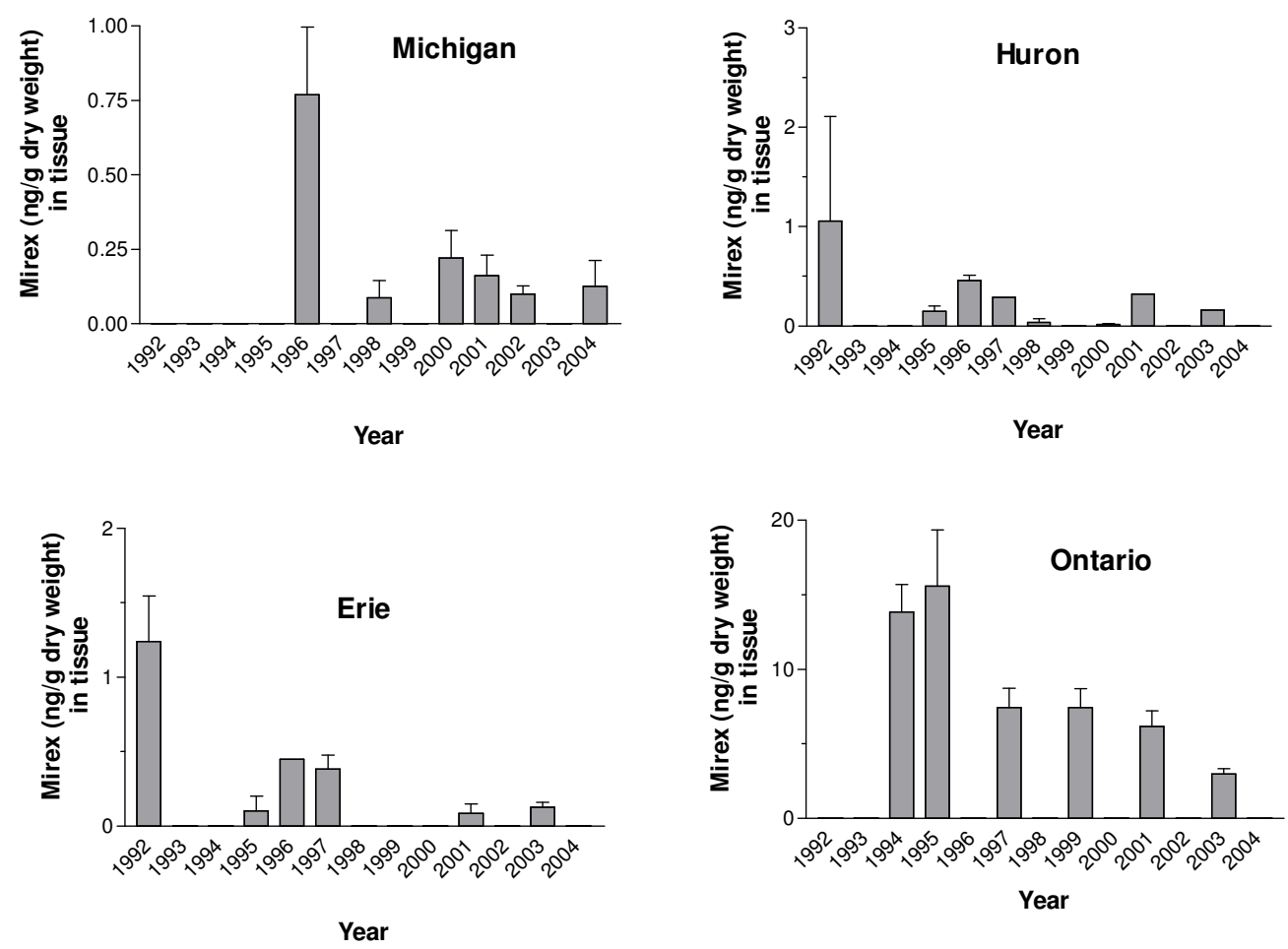

Fig. 5: Temporal trends of mirex concentration in Dreissena sp. assessed at each of the major Great Lakes. Error bars are standard error on the means. (Note difference in scale)
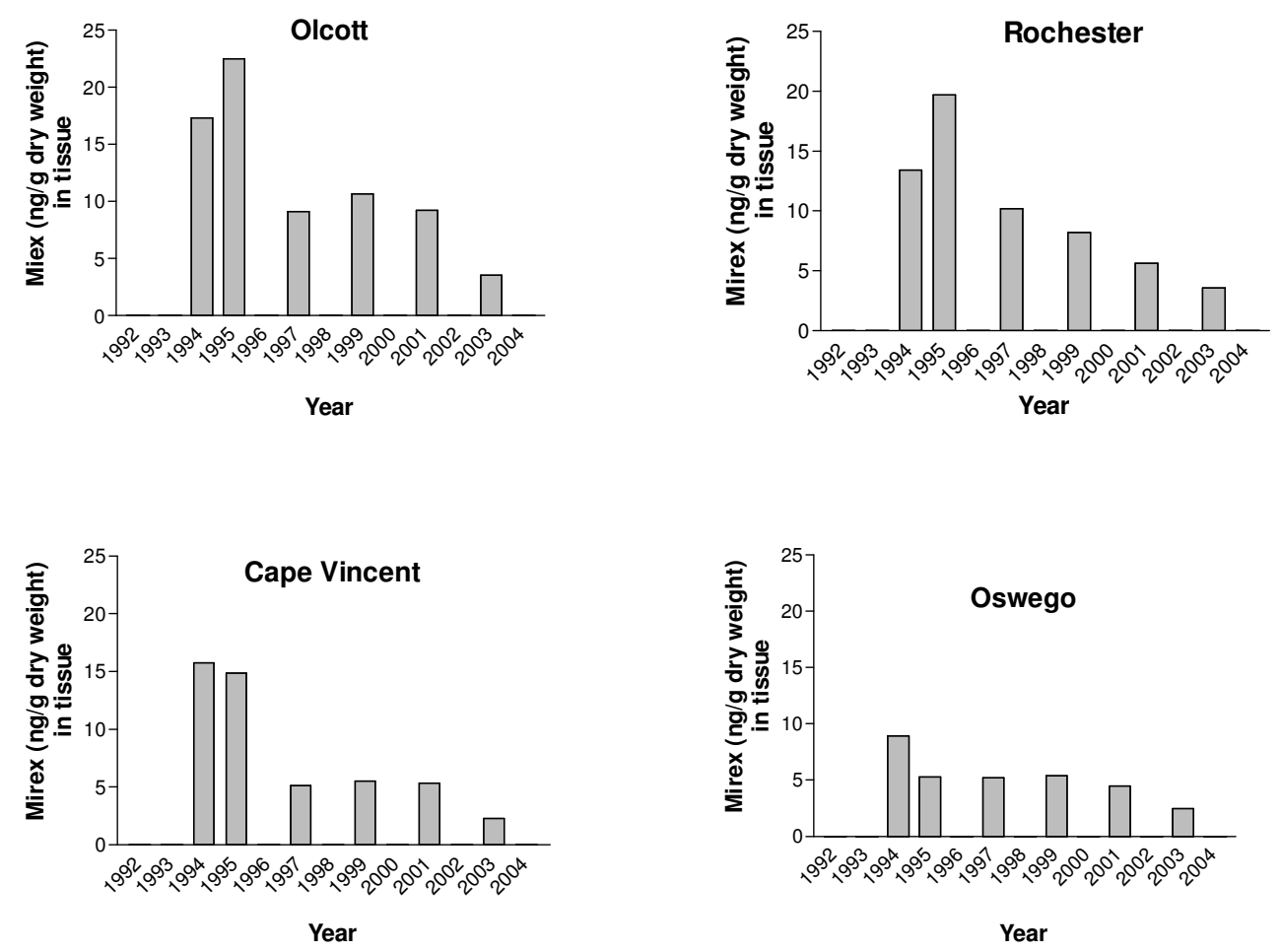

Fig. 6: Mirex concentration in Dreissena sp. showing assessment of temporal trends at the four sampling sites in Lake Ontario 
than $50 \%$ in salmon (Onchorhynchus kisutch and $O$. tshawytscha) from Lake Ontario. Additionally, the Herring Gull Monitoring Program reported a significant decline of mirex in herring gull eggs ${ }^{[26]}$.

Robertson and Lauenstein ${ }^{[27]}$ reported that mirex concentrations in tissue from Lakes Huron and Michigan were low while concentrations above $3.0 \mathrm{ng}$ $\mathrm{g}^{-1}$ were detected at sites east of Lake St. Clair. Comba et $a .^{[11]}$ and Velleux et al. ${ }^{[12]}$ have associated the mirex pollution of Lake Ontario to the release of industrial wastewater and runoff from landfills into the Niagara and Oswego Rivers both of which drain into the Lake Ontario. Therefore, the concentration ranges detected in Great Lakes are in agreement with previously published data and the pollution history of the lakes. Studies have documented transport and diffusion of the pesticide mirex to the St Lawrence River and estuary downstream from Lake Ontario ${ }^{[5,11]}$. The presence of mirex in the Lakes St. Clair, Erie and Michigan (Fig. 5) seems unexpected upon first observation because these water bodies are upstream from Lake Ontario and they have no direct connection with the Niagara and Oswego Rivers. Nevertheless, mirex residue in these lakes may be linked to non-point sources associated with the historical use of mirex as pesticide ${ }^{[3]}$ and the subsequent runoffs. Lake Erie-Old-Woman Creek (LEOW) site is located in a tributary of Lake Erie ${ }^{[28]}$. The relatively high mirex concentration in the sediment there may be linked to sedimentation of contaminants present in the Old-Woman Creek water. The Lake MichiganMilwaukee Bay (LMMB) sediment site however, is located offshore where concentration is expected to be relatively low due its physical location and nonexistence of direct anthropogenic sources.

In addition to the physical location of sample sites, the presence of mirex in lakes upstream from Lake Ontario that are at levels above the general detection limits $\left(0.04 \mathrm{ng} \mathrm{g}^{-1}\right)$ may be associated with agricultural runoff and hydrological transport. In the USA, mirex was used as pesticide and applied to farmlands ${ }^{[3]}$. Having an organic carbon /water partition coefficient $\left(\log \mathrm{K}_{\mathrm{oc}}\right)$ of $7.13^{[5]}$, mirex should stay strongly bound to the organic fraction of soil. Moreover, being non-biodegradable, mirex should persist in soil for a long time. Small amounts may however, be slowly leached from soils and transported into water bodies via runoff ${ }^{[3]}$. Additionally, the evidence of reversal flow in the Great Lakes system may have redistributed contaminants including mirex between Lakes Erie and St. Clair ${ }^{[29]}$. Using the Detroit River flow reversal of 1987, Derecki and Quinn ${ }^{[29]}$ found that occasionally, wind-driven currents and water level fluctuations combined to temporarily block the normal flow of the river forcing an upstream flow. These authors have concluded that flow reversals are unique hydraulic phenomena with implication for pollution transport. Therefore, the occasional reverse flows may cause transport of mirex between Lakes Erie and St. Clair.

Transport of contaminants from Lake Ontario into other water bodies is also possible via migrating fish such as salmon and eels ${ }^{[8,30]}$. Contaminated fish may migrate to other water bodies or swim upstream to their spawning grounds and possibly die. Transfer of mirex may then occur when other fish feed on the carcasses or the eggs, both of which contain mirex residues. Also, direct transfer into the water column and sediment can occur as a result of the decomposing dead fish. Using a mass balance calculation on the mirex budget of Lake Ontario, the amount of mirex removed by migrating eels was estimated to be approximately of $2.3 \mathrm{~kg}$ annually ${ }^{[30]}$. Further, mirex redistribution can occur when contaminated fish are preyed upon by aquatic birds such as herring gulls ${ }^{[31]}$ which may subsequently forage and die elsewhere. The high trophic level of fisheating herring gulls exposes them to elevated concentrations of mirex, making the herring gull eggs a monitoring tool ${ }^{[16,26]}$.

As a result of these biological and physicochemical processes, mirex has now become ubiquitous in the Great Lakes ecosystem to the point where the chemical is being detected in the entire food chain including fish and upland game birds ${ }^{[7,33,34]}$. However, the MWP data did not show detectable levels of mirex in both sediment and tissue at Lake Huron sites. In Lake Huron, the MWP has established four sites where the bottom substrates were sandy or consist of gravel and cobble materials. Sediments were either not collected (Lake Huron Thunder Bay-LHTB and Sagina Bay Sandy point-SBSP) or they had undetected levels of mirex (Sagina Bay Sagina River-SBSR and Lake Huron Black River-LHBR) due to the sandy nature of the sediments.

Based on the sedimentation rate model for Lake Ontario, Kemp and Harper ${ }^{[34]}$ have estimated that it will require hundreds of years before contaminated sediments are completely buried by mirex free sediment. As a persistent compound, mirex can be expected to have a long residence time in the environment; however, the relatively rapid declines in mirex concentrations in the Great Lakes systems indicated by the concentrations in mussel tissues suggest otherwise. The faster than anticipated decline in mirex concentrations implies that in addition to sedimentation, other mechanisms hastening decline might be at work. These mechanisms may include hydrological transport of mirex-bound to suspended particles, volatilization, photolysis, biological assimilation of the pesticide as well as biomass removal via fishing.

Water circulation in the Great Lakes basin, especially the outflow of water into the St. Lawrence River may be associated with the transport and removal of large amounts of suspended contaminants including mirex. 
The St. Lawrence River flows $\left(14,100 \mathrm{~m}^{3} \mathrm{~s}^{-1}\right)$ downstream $1300 \mathrm{~km}$ from Lake Ontario to the Gulf of St. Lawrence. The removal of mirex by the outflow of the St. Lawrence River was quantified by Lum et al. ${ }^{[30]}$ using mass balance models. These authors subsequently estimated the amount of mirex transported by the outflow of St. Lawrence River to be roughly $1.37 \mathrm{~kg}$ annually. Although this study did show how this annual value should gradually decrease over time, the essentials of the mass budget study was its capacity to show the dynamics of mirex in the Great Lakes system. Being the major outlet, the St. Lawrence River may therefore be one of the most important mechanisms for the removal of mirex from the Great Lakes system.

Mirex, although relatively inert, can be subjected to photolysis under the influence of UV light in the upper part of the water column to produce photomirex ${ }^{[35]}$. Comba et al. ${ }^{[11]}$ estimated the photomirex to mirex ratio to be 0.07 and concluded that the conversion of mirex to photomirex is limited. As with photolysis, volatilization has the potential to induce mirex reduction from the top of the water column. Mirex which has a Henry's Law Constant of $5.41 \times 10^{-2}\left(\mathrm{~m}^{3}\right.$ atm $\mathrm{mol}^{-1}$ ), can undergo volatilization, transferring a fraction of the compound into the atmosphere under ambient conditions ${ }^{[5]}$. Because mirex has a low Henry's Law Constant, Makarewicz et al. ${ }^{[25]}$ determined losses due to volatilization to be relatively small and comparable to those from the photolysis. The rates of mirex photolysis and volatilization may be minimal; however, the cumulative losses from these chemical processes coupled with the large surface area $(244,000$ $\mathrm{km}^{2}$ ) of the Great Lakes may contribute to a significant amount of mirex being removed.

Biological processes such as the trophic transfer and biomass removal (fishing) may contribute to a substantial loss of mass of mirex. The 1995 ATSDR report on mirex reviews an extensive literature of the bioaccumulation factors of the pesticide in wildlife including algae, amphipods, bivalves and fish. With variable density across the Great Lakes, zebra mussels may reach an estimated maximum of 50,000 individuals $\mathrm{m}^{-2}$ in some parts of the lakes ${ }^{[36]}$ and may be removing and accumulating considerable amounts of mirex from the water. Recent laboratory and field studies have confirmed that some species of crayfish, catfish, sunfish and round gobies prey heavily on zebra mussels ${ }^{[20-22]}$ suggesting that zebra mussels may be a vector by which mirex and other contaminants enter the food chain. Humans as apex predators are not excluded from this trophic transfer phenomenon. A New York State cohort study ${ }^{[10]}$ of anglers from 16 counties proximal to Lakes Erie and Ontario estimated that western New York anglers are being chronically exposed to a substantial fraction of mirex by consuming sport caught-fish in the Great Lakes. The combination of these biological processes coupled with fish harvesting may be playing an important part in the overall decline of mirex in the Great Lakes system.

Mirex concentration in Great Lakes is declining and the most recent MWP survey data reported in this paper are lower than the Wisconsin Department of Natural Resources for sediment quality guideline of 7.0 ng $\mathrm{g}^{-1}$ dry weight ${ }^{[37]}$ and the US Food And Drug Administration seafood consumption criterion of 500 $\mathrm{ng} \mathrm{g}^{-1}$ dry weight ${ }^{[38]}$. However, the continuing concern about mirex is its trophic level transfer and biomagnification potential. Therefore, mirex concentrations may be decreasing, but at its current levels, the chemical is still of concern because of human exposure risks through fish consumption ${ }^{[9,33]}$.

\section{CONCLUSION}

The mirex data from the NS\&T, MWP have been synthesized and mapped to illustrate the spatial distribution of mirex in the Great Lakes. Among the four Great Lakes monitored by the Mussel Watch Project, Lake Ontario, which received mirex contaminated waters from the Oswego and Niagara Rivers in the 1960s, continues to exhibit the highest mirex concentration in the region. Additionally the temporal trends indicate significant decreases in mirex concentrations since 1992. Results show that although an overall decreasing trend was observed, mirex concentrations are frequently above detection limits throughout the Great Lakes, with the highest levels found in Lake Ontario. Therefore, twenty five years after its ban, residues of mirex continue to be detected in the sediment and biota of the Great Lakes. With evidence that zebra mussels are being preyed upon by varieties of fish species, the emerging concern in the Great Lakes region is the human exposure to mirex via the consumption of sport fish.

\section{ACKNOWLEDGEMENTS}

The authors thank J. D. Christensen, T. McTigue, T. O'Connor, A. Y. Cantillo, M. J. Hameedi, I. Hartwell, C. Caldow and M. Kendall for their insight and critical reviews. We also wish to acknowledge staffs at the NOAA Great Lakes Environmental Research Laboratory for their technical assistance.

\section{REFERENCES}

1. Nalepa, T.F., D.J. Hartson, G.W. Gostenik, D.L. Fanslow and G.A. Lang, 1996. Changes in the freshwater mussel community of Lake St. Clair: from Unionidae to Dreissena polymorpha in eight years. J. Great Lakes Res., 22: 354-369.

2. Lauenstein, G.G. and A.Y. Cantillo, 1993. Sampling and analytical methods of the National Status and Trends Program, National Benthic Surveillance and Mussel Watch Projects: 19841992 update. NOAA Technical Memorandum NOS ORCA 71, Silver Spring, MD. 
3. International Program on Chemical Safety (IPCS), 1984. Environmental Health Criteria 44. World Health Organization Geneva.

4. US Environmental Protection Agency (EPA) 2001. Office of Pesticide Program (<http://www.epa.gov/oppfead1/international/pops. htm>). Sep. 9, 2005.

5. Halfon, E. and R.J. Allan, 1995. Modelling the fate of PCBs and mirex in aquatic ecosystems using the toxfate model. Environ. Intl., 21: 557-569.

6. US Environmental Protection Agency, 2004. Persistent Bioaccumulative and Toxic (PBT) Chemical program: Mirex (<http://www.epa.gov/pbt/mirex.htm>). Sep. 9, 2005.

7. Braune, M.B. and J.B. Malone, 2005. Organochlorines and trace elements in upland game birds harvested in Canada. Science of the Total Environment. Article in press 2005. Science Direct online. www.sciencedirect.com. Nov. 9, 2005.

8. US Agency for Toxic Substance and Disease Registry (ATSDR), 1995. Toxicology profile for mirex and chlordecone. Atlanta, GA: US Department of Health and Human Services, Public health Services.

9. Denham, M., S.M. Lawrence, G. Deane, M.V. Gallo, J. Ravenscroft and P.A. DeCaprio, 2005. Relationship of lead, mercury, mirex, dichlorodiphenyldichloroethylene,

hexachlorobenzene and polychlorinated biphenyls to timing of menarche among Akwesasne Mohawk girls. Pediatrics, 115: e127-e134.

10. Bloom, M.S., J.E. Vena, M.K. Swanson, K.B. Moysich and R.J. Olson, 2005. Profiles of orthopolychlorinated biphenyl congeners, dichlorodiphenyldichloroethylene,

hexachlorobenzene and Mirex among male Lake Ontario sportfish consumers: the New York state angler cohort study. Environ. Res., 97: 178-194.

11. Comba, M.E., R.J. Norstrom, C.R. MacDonald and K.L.E. Kaiser, 1993. A Lake Ontario-Gulf of St. Lawrence dynamic mass budget for mirex. Environ. Sci. Technol., 27: 2198-2206.

12. Velleux, M., S. Burns, J.V. DePinto and J.P. Hassett, 1995. A screening-level mass balance analysis of mirex transport and fate in the Oswego River. J. Great Lakes Res., 12: 95-111.

13. Eisler, R., 1985. Mirex hazards to fish, wildlife and invertebrates: A synoptic review. Biological Report 85(1.1). Fish and Wildlife Service Patuxent Wildlife Research Center. Laurel, MD.

14. Kaiser, K.L.E., 1978. Mirex: A previously unrecognized contaminant of fishes from Lake Ontario. Science, 185: 523-525.

15. Holdrinet, M., H. Van, R. Frank, R.L. Thomas and L.J. Hetling, 1978. Mirex in the sediments of Lake Ontario. J. Great Lakes Res., 4: 69-74.
16. Hebert, C.E., R.J. Norstrom and D.V.C. Weseloh, 1999. A quarter century of environmental surveillance: The Canadian Wildlife Service's Great Lakes Herring Gull Monitoring Program. Environ. Rev., 7: 147-166.

17. Guo, L., P.H. Santshi and S.M. Ray, 2001. Metal partitioning between colloidal and dissolved phases and its relation with bioavailability to American oysters. Marine Environ. Res., 54: 49-64.

18. Wang, W.X., N.S. Fisher and S.V. Lumoa, 1996. Kinetic determination of trace element bioaccumulation in the mussel Mytilus edulis. Marine Ecol. Prog. Ser., 140: 91-113.

19. Cho, Y-C., R.C. Frohnhoefer and G.-Y. Rhee, 2004. Bioaccumulation and redeposition of polychlorinated biphenyls by zebra mussels (Dreissena polymorpha) in the Hudson River. Water Res., 38: 769-777.

20. Bartsch, M., 2003. Density and size distribution of zebra mussels in the upper Mississippi River, Pool 8 and effects of predation. Upper Midwest Environmental Sciences Center. US Geological Survey.

21. Perry, W.L., D.M. Lodge and G.A. Lamberti, 1996. Impact of crayfish predation on exotic zebra mussels and native invertebrates in a lake-outlet stream. Can. J. Fish. Aquatic Sci., 54: 120-125.

22. Ghedotti, M.J., J.C. Smihula and G.R. Smith, 1995. Zebra mussel predation by round gobies in the laboratory. J. Great Lakes Res., 21: 665-669.

23. Lauenstein, G.G. and A.Y. Cantillo, 1998. Sampling and analytical methods of the NS\&T Program Mussel Watch Project: 1993-1996 update. NOAA Technical Memorandum NOS ORCA 130 Silver Spring, MD.

24. O'Connor, T.P., 2002. National distribution of chemical concentrations in mussels and oysters in the USA. Environ. Marine Res., 53: 117-143.

25. Makarewicz, J.C., E. Damaske, T.W. Lewis and M. Merner, 2003. Trend analysis reveals a recent reduction in mirex concentrations in Coho (Oncorhynchus kisutch) and Chinook (O. tshawytscha) Salmon from Lake Ontario. Environ. Sci. Technol., 37: 1521-1527.

26. Weseloh, V.D., P. Mineau and J. Struger, 1990. Geographical distribution of contaminants and productivity measures of herring gulls in the Great lakes: Lake Erie and connecting channels 1978/1979. The Sci. Total Environ., 91: 141-159.

27. Robertson, A. and G.G. Lauenstein, 1998. Distribution of chlorinated organic contaminants in dreissenid mussels along the southern shores of the Great Lakes. J. Great Lakes Res., 24: 608-619.

28. Lauenstein, G.G., A.Y. Cantillo, S.F. Kokkinakis, H.J. Jobling and R.R. Fay, 1997. Mussel Watch Project site descriptions, through 1997. NOAA technical Memorandum NOS ORCA 112, Silver Spring, MD. 
29. Derecki, J.A. and F.H. Quinn, 1990. Comparison of measured and simulated flows during the 15 December 1987 Detroit River flow reversal. J. Great Lakes Res., 16: 426-435.

30. Lum, K.R., K.L.E. Kaiser and M.E. Comba, 1987. Export of mirex from Lake Ontario to the St. Lawrence estuary. The Sci. Total Environ., 67: 4151.

31. Grasman, K.A., G.A. Fox, P.F. Scanlon and J.P. Ludwig, 1996. Organochlorine-associated immunosuppression in prefleding Caspian terns and herring gulls from the Great Lakes: an ecoepidemiological study. Environ. Health Perspective, 104, Suppl. 4.

32. Kim, K.S., M.J. Pastel, J.S. Kim and W.B. Stone, 1984. Levels of polychlorinated biphenyls, DDE and mirex in waterfowl collected in New York State, 1979-1980. Arch. Environ. Contam. Toxicol., 13: 373-381.

33. Elliot, J.E. and P.A. Martin, 1994. Chlorinated hydrocarbons and shell thinning in eggs of (Accipiter) hawks in Ontario, 1986-1989. Environ. Poll., 86: 189-200.
34. Kemp, A.L.W. and N.S. Harper, 1976. Sedimentation rates and sediment budget for Lake Ontario. J. Great Lakes Res., 2: 324-340.

35. Todoroff, E.C., M. Sevcik, D.C. Villeneuve, W.G. Foster and J.F. Jarrell, 1998. The effect of photomirex on the in vitro perfused ovary of the rat. Reproductive Toxicol., 12: 305-316.

36. Fahnenstiel, G.L., G.A. Lang, T.F. Nalepa and T.H. Johengen, 1995. Effects of zebra mussel (Deissena polymorpha) colonization on water quality parameters in Siginaw Bay, Lake Huron. J. Great Lakes Res., 21: 435-448.

37. Wisconsin Department of Natural Resources (WDNR), 2003. Consensus-Based Sediment Quality Guidelines. Recommendations for Use \& Application Interim Guidance. WT-732 2003.

38. Williams, D.J. and M.L. O'Shea, 2003. Niagara River toxic management plan (NRTMP) progress report and work plan. Environmental Canada and US Environmental Protection Agency. 